\title{
Targeting Oxidative Stress in Septic Acute Kidney Injury: From Theory to Practice
}

\author{
Connie P. C. Ow ${ }^{1,2}{ }^{\text {, Anton Trask-Marino }}{ }^{1}$, Ashenafi H. Betrie ${ }^{1,3}\left(\mathbb{D}\right.$, Roger G. Evans ${ }^{1,4}\left(\mathbb{D}\right.$, Clive N. May ${ }^{1,5}$ \\ and Yugeesh R. Lankadeva ${ }^{1,5, *}$
}

1 Preclinical Critical Care Unit, Florey Institute of Neuroscience and Mental Health, Melbourne, VIC 3052, Australia; ow.peichenconnie73@ncvc.go.jp (C.P.C.O.); traskmarinoanton@gmail.com (A.T.-M.); ashenafi.betrie@florey.edu.au (A.H.B.); roger.evans@monash.edu (R.G.E.); clive.may@unimelb.edu.au (C.N.M.)

2 Department of Cardiac Physiology, National Cerebral and Cardiovascular Center Research Institute, Osaka 564-8565, Japan

3 Melbourne Dementia Research Centre, Florey Institute of Neuroscience and Mental Health, Melbourne, VIC 3052, Australia

4 Cardiovascular Disease Program, Biomedicine Discovery Institute and Department of Physiology, Monash University, Melbourne, VIC 3800, Australia

5 Department of Critical Care, Melbourne Medical School, University of Melbourne, Melbourne, VIC 3052, Australia

* Correspondence: yugeesh.lankadeva@florey.edu.au; Tel.: +61-3-8344-0417; Fax: +61-3-9035-3107

Citation: Ow, C.P.C.; Trask-Marino, A.; Betrie, A.H.; Evans, R.G.; May, C.N.; Lankadeva, Y.R. Targeting Oxidative Stress in Septic Acute Kidney Injury: From Theory to Practice. J. Clin. Med. 2021, 10, 3798. https://doi.org/10.3390/jcm10173798

Academic Editor: Giuseppe Regolisti

Received: 29 June 2021

Accepted: 23 August 2021

Published: 25 August 2021

Publisher's Note: MDPI stays neutral with regard to jurisdictional claims in published maps and institutional affiliations.

Copyright: (c) 2021 by the authors Licensee MDPI, Basel, Switzerland. This article is an open access article distributed under the terms and conditions of the Creative Commons Attribution (CC BY) license (https:// creativecommons.org/licenses/by/ $4.0 /)$.

\begin{abstract}
Sepsis is the leading cause of acute kidney injury (AKI) and leads to increased morbidity and mortality in intensive care units. Current treatments for septic AKI are largely supportive and are not targeted towards its pathophysiology. Sepsis is commonly characterized by systemic inflammation and increased production of reactive oxygen species (ROS), particularly superoxide. Concomitantly released nitric oxide (NO) then reacts with superoxide, leading to the formation of reactive nitrogen species (RNS), predominantly peroxynitrite. Sepsis-induced ROS and RNS can reduce the bioavailability of $\mathrm{NO}$, mediating renal microcirculatory abnormalities, localized tissue hypoxia and mitochondrial dysfunction, thereby initiating a propagating cycle of cellular injury culminating in AKI. In this review, we discuss the various sources of ROS during sepsis and their pathophysiological interactions with the immune system, microcirculation and mitochondria that can lead to the development of AKI. We also discuss the therapeutic utility of N-acetylcysteine and potential reasons for its efficacy in animal models of sepsis, and its inefficacy in ameliorating oxidative stress-induced organ dysfunction in human sepsis. Finally, we review the pre-clinical studies examining the antioxidant and pleiotropic actions of vitamin $C$ that may be of benefit for mitigating septic AKI, including future implications for clinical sepsis.
\end{abstract}

Keywords: septic acute kidney injury; oxidative stress; hypoxia; $\mathrm{N}$-acetylcysteine; vitamin $\mathrm{C}$

\section{Introduction}

Sepsis is the leading cause of acute kidney injury (AKI), accounting for approximately $50 \%$ of cases of renal dysfunction in intensive care units [1]. Development of AKI during sepsis is both a significant and an independent prognostic factor for prolonged hospitalization and in-hospital death [2]. There is also mounting epidemiological evidence that survivors of either mild or short episodes of AKI are predisposed to greater risk of developing chronic kidney disease (CKD) and end-stage renal disease in later life [3]. Antibiotics and resuscitation with fluids and vasopressors are currently the mandated treatments for human sepsis. Renal replacement therapy (RRT) is recommended for patients who develop severe septic AKI [4]. However, these are mainly palliative interventions aimed at keeping the patients alive in the hope that the kidneys recover. Accordingly, a better understanding 
of the pathophysiology of septic AKI is required to formulate effective mechanism-guided interventional strategies.

Although global renal ischemia has been proposed as a cause of septic AKI [5], there is both experimental and clinical evidence challenging this dogma. Histopathological investigations performed on post-mortem kidney tissue from patients that succumbed to septic AKI demonstrate heterogenous focal, patchy tubular injury, with minimal tubuleepithelial death $(<5 \%)$, apical vacuolization and minor focal mesangial expansion, which are not characteristic of severe renal ischemic injury [6,7]. In addition, there is compelling evidence from clinically relevant ovine and porcine models of sepsis that AKI develops even in the absence of global renal ischemia [8-10]. Similarly to the histopathological findings in human sepsis, acute tubular necrosis and tubular cell apoptosis were not characteristic of AKI in such large mammalian models of hyperdynamic sepsis [9,11]. During inflammatory conditions such as sepsis, there appears to be an uncoupling of the renal microcirculation from the macrocirculation [12]. In ovine sepsis, selective renal medullary tissue ischemia and hypoxia precede the development of AKI by $12-24 \mathrm{~h}$, despite increases in renal blood flow and renal cortical perfusion and oxygenation [13-15]. Oxidative stress plays a critical role in promoting adaptive responses to localized tissue hypoxia by stabilization of hypoxia inducible factors (HIF), which promotes the transcription of multiple genes [16]. However, in sepsis there is an imbalance between reactive oxygen species (ROS) and reactive nitrogen species (RNS) and the host's antioxidant defense mechanisms. In this review, we outline the sources and roles of oxidative and nitrosative stress in the pathophysiology of septic AKI with an emphasis on its interactions with inflammation, microcirculatory abnormalities, tissue hypoxia and mitochondrial dysfunction. We also outline recent pre-clinical and clinical studies that have investigated the use of antioxidants, principally $\mathrm{N}$-acetylcysteine (NAC) and vitamin C, as a potential therapeutic strategy for septic AKI.

\section{Interactions between the Septic Inflammatory Cascade and Oxidative Stress}

The inflammatory response is the body's first line of defense against invading pathogens, but this can also be a critical initiating factor for renal injury. In sepsis, inflammatory mediators, including pathogen- and damage-associated molecular patterns, are released into the intravascular area and are detected by Toll-like receptors on tubular and endothelial cells [17]. Activation of these receptors subsequently propagates a myriad of downstream processes contributing to tubular reparation, vascular rarefaction and amplification of pro-inflammatory immune modulators at sites of injury, leading to vascular congestion and endothelial dysfunction [18]. These processes appear to converge to stimulate superoxideinduced amplification of tissue hypoxia and cellular injury (Figure 1).

Sepsis-induced tubular and vascular injuries, in concert with oxidative stress, trigger the recruitment of polymorphonuclear neutrophils, setting in motion a cascade of immunomodulatory events which leads to downstream production of ROS and RNS, further propagating injury [19]. Neutrophils have the ability to generate superoxide through a complex process known as the "oxidative burst" [20,21]. Neutrophils express multiple receptors, including the $\beta 1, \beta 2$ and $\beta 3$ integrins, which when activated bind to fibronectin, fibrinogen and collagen, mediating their translocation to the extracellular matrix by Pselectins and E-selectins [22]. Here, a series of signaling cascades ultimately leads to the downstream release of intracellular calcium and the formation of the nicotinamide adenine dinucleotide phosphate (NADPH) oxidase complex, resulting in the production of ROS $[20,21]$. Furthermore, inducible nitric oxide synthase (iNOS) activity is upregulated within immune cells (Figure 2). This increases the production of nitric oxide (NO), which can react with the ROS produced by NADPH oxidase to form the RNS peroxynitrite (Figure 2). Peroxynitrite contributes to nitrosative damage, such as S-nitrosylation of proteins, thereby affecting normal functioning of proteins. The notion of ROS-induced vascular injury is supported by the observation in patients with sepsis of extensive production of superoxide from leucocyte microparticles, which in turn enhances adhesion molecules' activity and endothelial activation [23]. Moreover, high plasma levels of lipid peroxidation 
markers (F2-isoprostanes and isofurans) have been strongly associated with AKI in patients with sepsis [24].

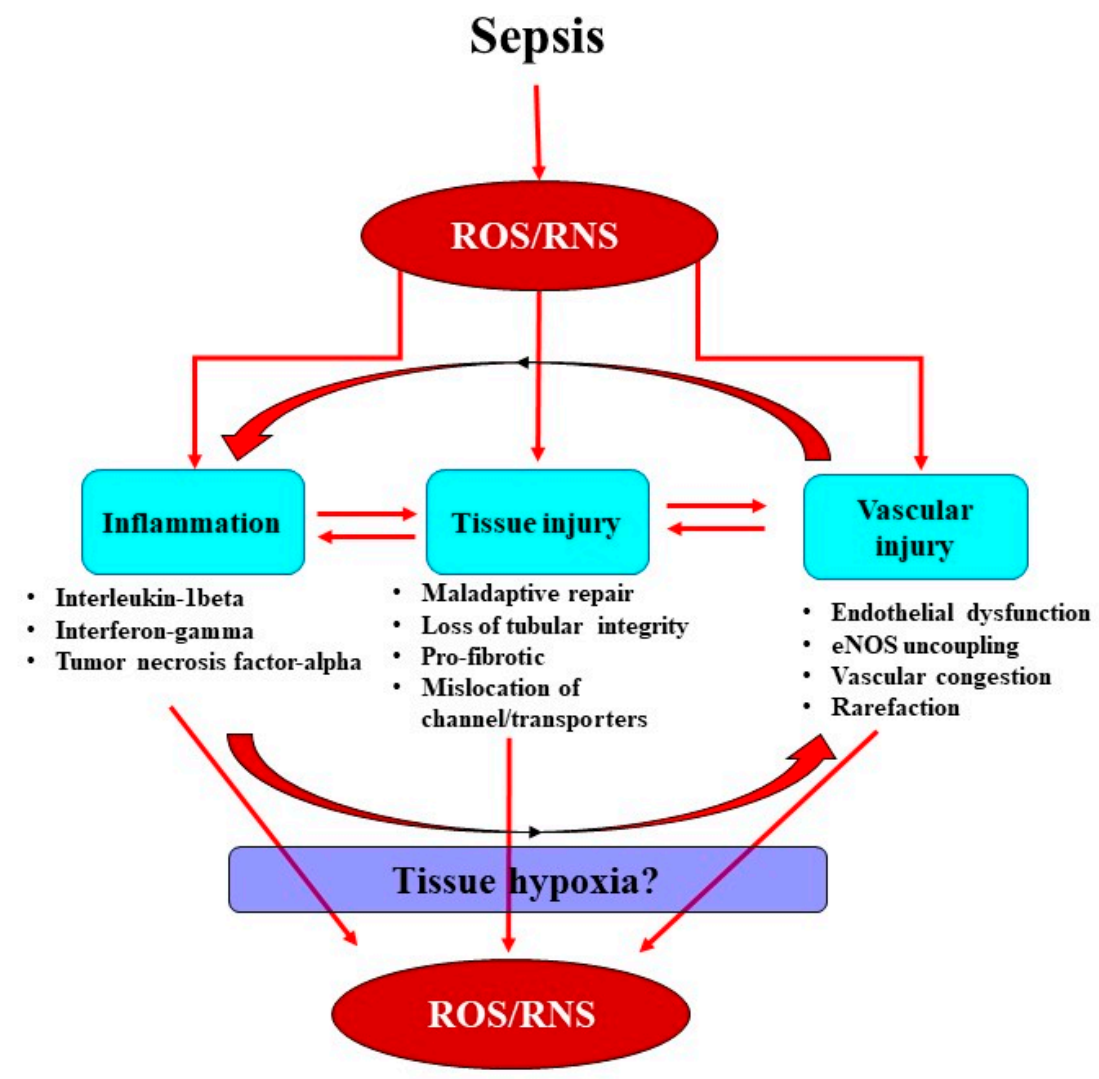

Figure 1. Schematic of the proposed relationships among sepsis-induced production of reactive oxygen species (ROS) and reactive nitrogen species (RNS) and inflammation, tissue, and vascular injury. ROS and RNS result in enhanced production of immune-modulatory cells at sites of injury in vessels and tubules, thereby initiating a complex cascade of inflammation and injury. Importantly, tissue and vascular injuries in severe sepsis can have deleterious consequences, as they can contribute to an uncoupling of endothelial nitric oxide synthase (eNOS), mediating endothelial dysfunction and tissue hypoxia, thereby enhancing the accumulation of ROS and RNS.

The generation of oxidative stimuli by neutrophils further attracts the pro-inflammatory chemokine ligand-5 and intracellular adhesion molecule- 1 , which are important factors that facilitate the recruitment of leukocytes to sites of tissue injury $[25,26]$. Mobilized and activated leukocytes initiate a cytokine storm involving the recruitment of pro-inflammatory cytokines, including interleukin-1-beta (IL-1 $\beta$ ), interferon-gamma (IFN- $\gamma$ ) and tumor necrosis factor-alpha (TNF- $\alpha$ ) $[27,28]$, which can lead to the further production of ROS (Figure 1). Indeed, inflammatory and oxidative stress biomarkers such as TNF- $\alpha$, IL- $1 \beta$, myeloperoxidase activity, malondialdehyde and hydrogen peroxide $\left(\mathrm{H}_{2} \mathrm{O}_{2}\right)$ are all reported to be significantly elevated in patients with septic AKI [29]. Collectively, the initial inflammatory cascade in sepsis appears to be a critical initiating factor in the propagation of oxidative stress, which can have deleterious effects on renal microcirculation. 


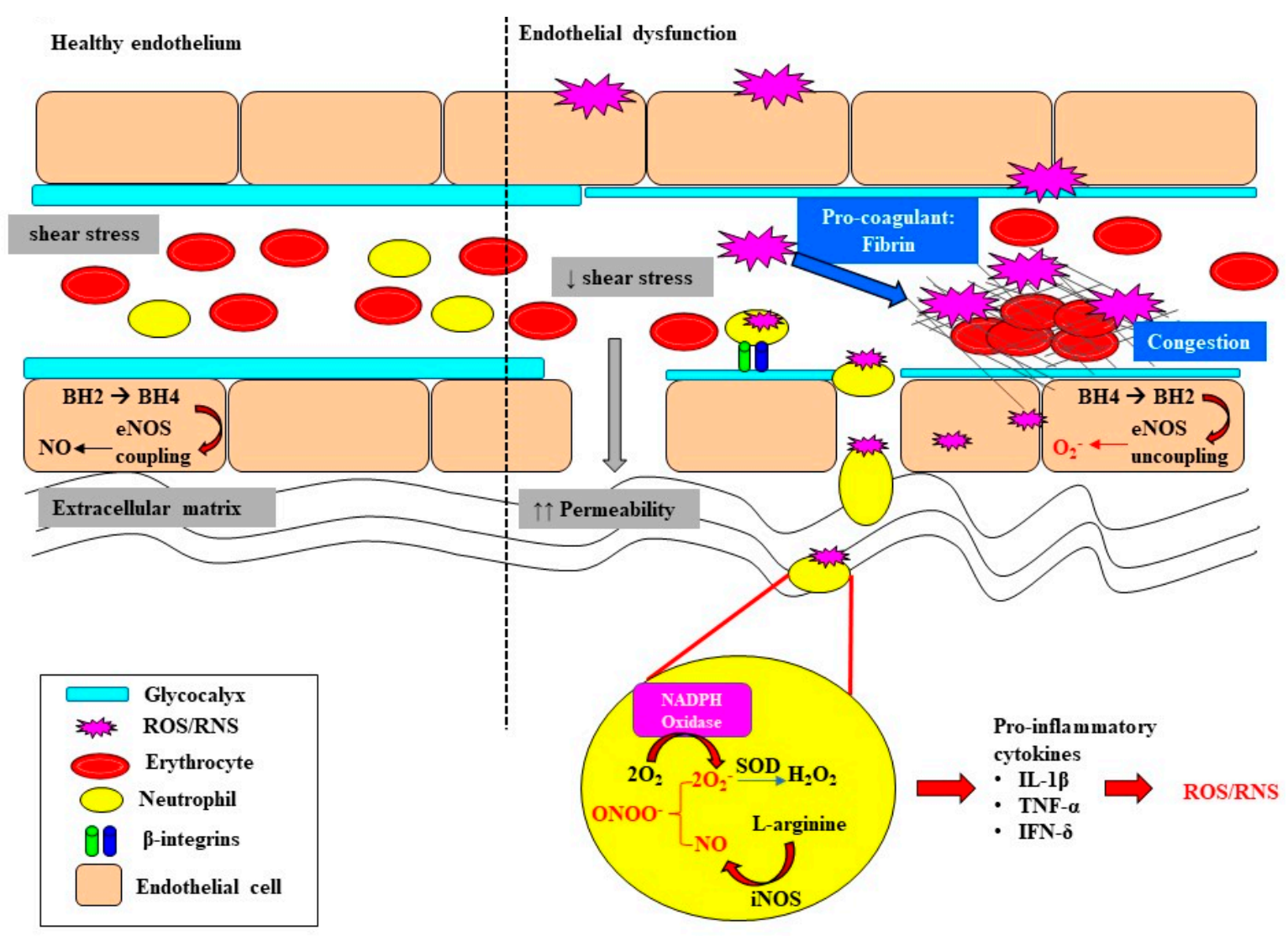

Figure 2. A schematic outlining the initiation of oxidative damage to the endothelium, the downstream consequences for endothelial dysfunction and the propagation of oxidative stress. The layer of glycocalyx lining the apical surface of endothelial cells is important for the maintenance of shear-stress and flow-mediated nitric oxide (NO) release and vasodilation of the endothelium. Sepsis-induced oxidative stress leads to glycocalyx thinning and shedding, resulting in the loss of gap junctions, and subsequently increased permeability and vascular leakage. Loss of gap junctions also greatly facilitates extravasation of neutrophils in the circulation, mediated by $\beta$-integrins, through to the extracellular matrix. The resultant superoxide $\left(\mathrm{O}_{2}{ }^{-}\right)$that is formed can interact with nitrosative species generated by inducible nitric oxide synthase (iNOS), forming the highly reactive peroxynitrite $\left(\mathrm{ONOO}^{-}\right)$and then hydrogen peroxide $\left(\mathrm{H}_{2} \mathrm{O}_{2}\right)$. Oxidative bursts from neutrophils contribute to enhanced oxidative damage and the downstream production of pro-inflammatory cytokines which have the intrinsic capability of producing reactive oxygen species (ROS) and reactive nitrogen species (RNS). Oxidative stress can also induce the recruitment of pro-coagulants to the site of injury, resulting in vascular congestion, ultimately impeding blood flow. Increased oxidative stress at the endothelium depletes and oxidizes the pool of tetrahydrobiopterin (BH4), resulting in the uncoupling of endothelial nitric oxide synthase (eNOS) in endothelial cells, thereby enhancing the production of ROS. Interleukin-1beta (IL- $\beta$ ); tumor necrosis factor-alpha (TNF- $\alpha$ ), interferon-gamma (IFN- $\delta$ ).

\section{Oxidative Stress Exacerbates Microcirculatory Abnormalities and Vascular Rarefaction}

Endothelial dysfunction and microvascular rarefaction have been described as common pathophysiological features of AKI and are postulated to be critical factors mediating progression to CKD following recovery from AKI [30-32]. The NO system is an important regulator of vascular tone within the renal microcirculation, but it can be deleteriously affected in sepsis (Figure 2). In the healthy state, the biosynthesis of NO by vascular endothelial cells is dependent on the coupling state of endothelial nitric oxide synthase (eNOS) and the bioavailability of the co-factor tetrahydrobiopterin (BH4) [33]. When endogenous levels of the co-factor $\mathrm{BH} 4$ are sufficient, L-arginine is coupled with the reduction of oxygen, leading to the production of the potent vasodilator NO [33,34]. However, when $\mathrm{BH} 4$ levels are low, eNOS is uncoupled and superoxide is produced instead. Furthermore, $\mathrm{BH} 4$ is highly susceptible to oxidization to $\mathrm{BH} 2$ when levels of superoxide are high, fur- 
ther depleting the pool of the rate limiting co-factor BH4 [35,36]. Uncoupling of eNOS is reported to contribute to the pathophysiology of a myriad of kidney diseases arising from diabetes, hypertension and ischemia-reperfusion injury [37,38]. Intravenous supplementation with $\mathrm{BH} 4$ in an ovine model of sepsis improved microvascular dysfunction via increasing the number of perfused vessels, the proportion of perfused small vessels and the microvascular index within the sublingual circulation [39]. In an ovine model of severe septic AKI induced by intravenous infusion of live Escherichia Coli for $48 \mathrm{~h}$, eNOS gene expression was selectively down regulated in the renal medulla, but not the renal cortex [11]. However, whether an uncoupling of eNOS contributes to the early onset of microcirculatory abnormalities reported within the renal medulla in ovine septic AKI [13] warrants further investigation.

In sepsis, excessive superoxide generation and accumulation, in tandem with inflammation, also results in direct structural damage to the vasculature, resulting in vascular leakage and tissue edema (Figure 2) [40]. The endothelial glycocalyx is a crucial regulator of endothelial function and vascular tone. The endothelial glycocalyx lining the apical surface of the endothelium, consisting of hyaluronic acid, heparan sulphate, glycoproteins and proteoglycans, ensures the integrity of vascular permeability, so it protects against vascular leakage, coagulation and persistent inflammation (Figure 2) [41,42]. It is also an important mechano-transducer, as it senses shear stress, thereby contributing to shear-stress mediated NO production and vasodilation. Under pathological conditions characterized by oxidative stress, the production of hyaluronidases that catalyze the depolymerization and degradation of hyaluronic acid of the glycocalyx is upregulated. The resultant shedding and thinning of the endothelial glycocalyx not only increases vascular permeability [41,43], but also compromises microcirculatory perfusion in sepsis [44,45]. For example, the thinning and shedding of the endothelial glycocalyx can decrease the ability of the endothelium to respond to shear-stress-mediated release of NO (Figure 2) [45]. Plasma levels of endothelial glycosaminoglycans in patients who survived sepsis were double those compared with healthy volunteers [46]. Moreover, the shedding of vascular endothelial cadherin, a protein essential for maintenance of gap junctions between endothelial cells, was significantly greater in septic patients with AKI that required RRT compared with those without AKI [47]. These clinical observations support the notion that the loss of endothelial integrity may play a crucial role in driving microcirculatory abnormalities in septic AKI.

The damaged endothelium also attracts leukocytes to the site of injury, as part of the innate immune response facilitated by the exposed intercellular and vascular cell adhesion molecules. This homing of pro-inflammatory cells, in conjunction with compromised gap junctions, leads to extravasation of the pro-inflammatory cells from the endothelium into the surrounding tissue, contributing to persistent inflammation [48]. Notably, inflammatory cells can generate ROS themselves and so reduce NO bioavailability [48], thereby contributing to the extensive pool of superoxide, essentially setting up a vicious cycle of oxidative stress, inflammation and vascular injury [19] (Figure 1). Sepsis-induced microvascular injury can also release microparticles into the systemic circulation. Microparticles are cell membrane-derived particles that consist of vasoconstrictive compounds such as prostaglandin E2, thromboxane A2, inflammatory mediators, pro-coagulants and fibrin. Thus, microparticles can act as localized sources of oxidative stress, inflammation and disseminated intravascular coagulopathy, resulting in vascular congestion [49]. It is conceivable that these microcirculatory perturbations may be amplified, especially within the smaller arteries of the renal medullary vasa recta, which may explain why the renal medulla is susceptible to developing hypoxia during sepsis.

\section{Renal Medullary Tissue Hypoxia: A Critical Event in Acute Kidney Injury?}

Renal medullary hypoxia is emerging as a common pathophysiological feature of AKI arising from sepsis [13,50], cardiopulmonary bypass [51,52] and radiocontrast-induced nephropathy [53]. Furthermore, renal medullary hypoxia has been implicated as an important driver in the transition and/or propensity for progression from AKI to CKD [54,55]. 
The relatively high metabolic requirements of the tubular elements in the renal medulla, coupled with the topography of vascular and tubular architecture within the medulla, result in a steep oxygen gradient between the capillaries (vasa recta) and both the thick and thin ascending limbs of the loop of Henle and the collecting ducts [56]. There is also the potential for diffusive oxygen shunting in the renal medullary microcirculation (from descending to ascending vasa recta), which could further compromise renal medullary oxygen delivery [57]. In healthy sheep, graded occlusion of the renal artery and thus progressive reductions in renal blood flow resulted in proportionally greater degrees of renal medullary ischemia and hypoxia compared with a renal cortex indicative of an intrinsic deficit in the autoregulatory capacity of the renal medullary microcirculation [58]. Accordingly, under pathophysiological settings such as sepsis, renal medullary microcirculatory perturbations leading to even modest reductions in medullary oxygen delivery or increases in oxygen consumption can have adverse consequences for medullary tissue oxygenation.

Renal medullary hypoxia can be a major driver of a cascade of events leading to cellular injury, vascular injury and tubular dysfunction [59]. Acute renal insults, including endotoxemia, can both increase renal tissue oxygen consumption and reduce tissue oxygen delivery. For example, these changes can result in tubular injury and obstruction, and mislocalization of $\mathrm{Na} / \mathrm{K}$-ATPase and transport proteins within renal tubular epithelial cells, thereby reducing the efficiency of oxygen utilization for sodium reabsorption [60]. In the context of the current review, it is also relevant that oxidative stress can increase tubular oxygen consumption both by reducing the efficiency of ATP production within the mitochondria and/or by enhancing oxygen utilization for tubular sodium reabsorption [61]. Moreover, renal insults that acutely compromise vascular integrity or chronically promote vascular rarefaction can reduce renal medullary oxygen delivery and further worsen tissue hypoxia. In a clinically relevant ovine model of gram-negative sepsis, the development of renal medullary hypoxia preceded AKI, as detected by elevated plasma creatinine and oliguria, by up to $12-24 \mathrm{~h} \mathrm{[13-15].} \mathrm{In} \mathrm{the} \mathrm{same} \mathrm{model} \mathrm{of} \mathrm{ovine} \mathrm{sepsis,} \mathrm{bladder} \mathrm{urinary} \mathrm{oxy-}$ genation was validated to provide a reliable estimate of renal medullary tissue oxygenation during development of septic AKI [15] and in response to clinical interventions, including resuscitation with fluids [62], vasopressors [14] and diuretics [63]. In subsequent human studies, the presence of renal tissue medullary hypoxia, as indirectly assessed by measurement of bladder urinary hypoxia was reported in patients with septic AKI [64]. Cellular protective mechanisms driven by HIFs can protect the kidneys when tissue hypoxia is mild and/or brief, but they can fail when hypoxia is severe and/or protracted, as can occur during sepsis [65].

HIFs are cellular oxygen sensors. Stabilization of the $\alpha$-subunit at low oxygen concentrations results in the formation of a dimer with the $\beta$-subunit. This dimer then translocates to the nucleus and binds to hypoxia response elements, resulting in altered transcription of a myriad of proteins essential for many key signaling pathways [66,67]. The upregulation and stabilization of HIFs is adaptive because it results in the production of erythropoietin, which promotes the production of red blood cells $[68,69]$. This increases blood oxygen carrying capacity, so it has the potential to ameliorate tissue hypoxia. Another important protein that is upregulated by the stabilization of HIFs is eNOS, which potentially increases NO bioavailability and ameliorates vasoconstriction, thereby limiting the further propagation of both hypoxia and ROS/RNS [66]. However, HIFs can be a double-edged sword because extensive production of HIFs in response to prolonged hypoxia in severe sepsis can result in excessive production of vasoconstrictive and ROS-inducing proteins, such as iNOS [70], and proteins that contribute to fibrogenesis [71]. Germane to such observations, an early onset of renal medullary hypoxia in sepsis resulting in prolonged phases of tissue hypoxia may lead to the destabilization of HIFs that propagate oxidative and nitrosative injuries, culminating in AKI. Supporting this notion, HIF- $1 \alpha$ gene expression was selectively downregulated within the renal medulla in septic sheep with severe AKI after $48 \mathrm{~h}$ of sepsis [11]. 
It must be acknowledged that the mechanistic link between renal medullary hypoxia and reduced glomerular filtration rate remains unidentified in AKI and may differ depending on the etiology of AKI. It is, however, conceivable that prolonged tissue hypoxia, particularly in metabolically active regions of the kidney such as the renal medulla, induces mitochondrial dysfunction, resulting in increased ROS and thus further amplification of renal cellular injuries.

\section{Sepsis-Induced Mitochondrial Dysfunction Activates Production of ROS}

Mitochondrial dysfunction is proposed to be both a cause and consequence of renal hypoxia in the pathogenesis of septic AKI [72,73]. Mitochondria are the main consumers of oxygen within the kidneys. Thus, the production of physiological levels of mitochondrial ROS in the mitochondrial matrix is important because ROS serve as signals and regulators for a myriad of biological processes. These include adaptation to hypoxia through regulating the stabilization of HIFs [74]; facilitating the formation of autophagosomes through oxidation of the cysteine protease autophagy-related gene- 4 by $\mathrm{H}_{2} \mathrm{O}_{2}$ [75]; and ROS-dependent activation of phosphoinositide- 3 kinase, leading to downstream production of pro-inflammatory cytokines, including caspase-1, IL-1 $\beta$ and IL-18 [76]. However, as cells experience prolonged periods of hypoxia, there is a change in metabolism and poor utilization of the available oxygen for ATP production in the mitochondrial electron transport chain, resulting in increased leakage of electrons and elevated production of free radicals/ROS $[77,78]$. Mitochondria use oxygen as the final acceptor of the respiratory chain, but its incomplete reduction can also produce ROS, especially superoxide [79]. Complex III of the electron transport chain is the inherent oxygen sensor during acute hypoxia, and it regulates the production of superoxide inversely with oxygen availability [80]. The transition of complex I from the active to "de-active" form was also reported to have the capacity to produce ROS outbursts during acute hypoxia [81]. Patients with septic AKI have elevated levels of receptor-interacting protein kinase-3 (RIPK3) in urine and plasma [82]. RIPK3 promotes oxidative stress and mitochondrial dysfunction in kidney tubular epithelial cells by increasing the expression and mitochondrial translocation of NADPH oxidase 4 and inhibition of mitochondrial complexes I and III [82-84]. It is therefore not surprising that mitochondrial injury has been commonly related to multi-organ dysfunction in patients with sepsis [6,85].

There are pre-clinical and clinical studies demonstrating that the adaptive processes of mitochondrial fission are downregulated in sepsis, which likely contributes to the loss of mitochondrial mass, thereby propagating ROS-induced damage during septic AKI. Sepsis is associated with considerable morphological changes in mitochondria. These changes include reduced numbers of cristae due to swelling of the inter-cristae space and the mitochondrial matrix, and vacuolation within the mitochondria space [82,86]. Depending on the severity of mitochondrial damage, the removal of mitochondria can be carried out by two pathways: mitophagy and apoptosis (Figure 3). Localized and extensive morphological aberrations within the mitochondria can lead to the accumulation of superoxide, eventually causing the opening of mitochondrial membrane channels. This leads to reduced mitochondrial membrane potential, localized to the site of injury, thereby further enhancing production of ROS [87]. Furthermore, increasing levels and/or accumulation of ROS can result in the upregulation of uncoupling protein-1 [88], consequently resulting in excessive proton leakage and hampering the production of ATP [89]. In this case, because the damage tends to be localized, the mitochondrion is targeted for mitochondrial fission, followed by subsequent removal of the damaged portion of the mitochondrion by mitophagy (Figure 3). During mitochondrial fission, "pinching" of the mitochondrial membrane occurs at the injury site, which is facilitated by the assembly of dynamin-related protein-1 that facilitates the removal of the damaged portion of the mitochondria from the undamaged portion (Figure 3) [90]. Following this, PTEN-induced kinase 1 and E3 ubiquitin-protein ligase (Parkin) proteins are recruited to the damaged mitochondrion, which ultimately forms an autophagosome and is removed by mitophagy [90]. Mitochondrial fusion proteins, 
mitofusin and mitochondrial dynamin-like GTPase, are recruited to the remaining healthy portion of the mitochondrion, which then fuses with an adjacent healthy mitochondrion (Figure 3). Thus, mitochondrial fission, followed by fusion, in this case, is seemingly an important adaptive reparative process because it not only arrests mitochondrial damage, but also prevents excessive loss of mitochondrial mass, thereby limiting ROS-induced injury. Supporting this notion, decreased expression of both mitochondrial PINK1 and Parkin mRNA has been reported in biopsies derived from patients who succumbed to severe septic AKI [91].

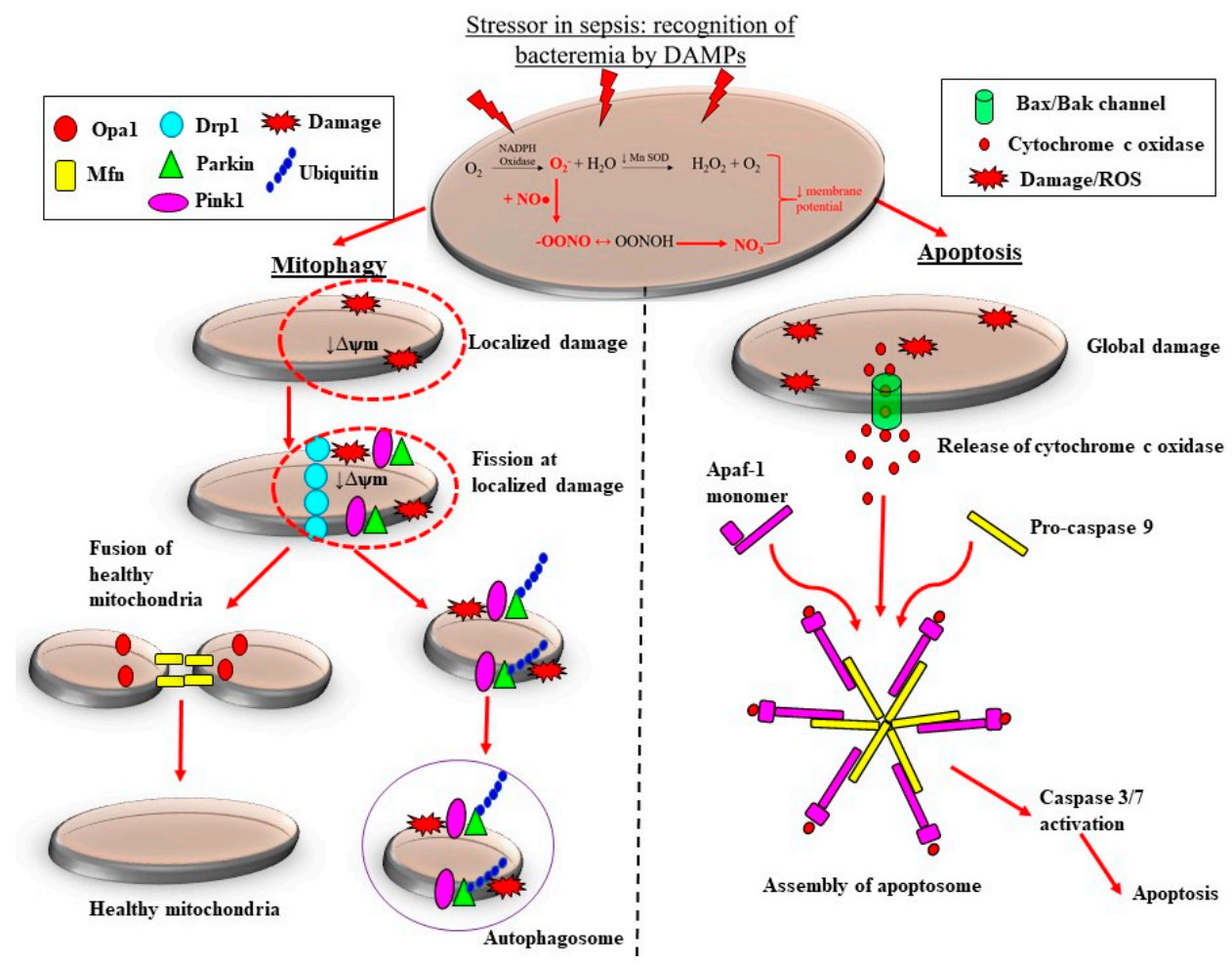

Figure 3. Adaptive and maladaptive responses of the mitochondria to sepsis-induced oxidative stress. Increased production of superoxide $\left(\mathrm{O}_{2}{ }^{-}\right)$by nicotinamide adenine dinucleotide phosphate (NADPH) oxidase coupled with the reduced activity of manganese superoxide dismutase (MnSOD) results in the accumulation of $\mathrm{O}_{2}{ }^{-}$. Cytosolic nitric oxide (NO) produced by inducible nitric oxide synthase (iNOS) reacts with $\mathrm{O}_{2}{ }^{-}$, forming the highly reactive peroxynitrite $\left(\mathrm{ONOO}^{-}\right)$. The accumulation of $\mathrm{O}_{2}{ }^{-}$and $\mathrm{ONOO}^{-}$results in persistent oxidative stress and a reduction in mitochondrial membrane potential $(4 \mathrm{~m})$ and so mitochondrial dysfunction. In the case of localized mitochondrial damage, mitochondrial quality control mechanisms are activated which arrest mitochondrial dysfunction and limit excessive mitochondrial loss. Recruitment of mitochondrial fission proteins to sites of injury targets the damaged portions of the mitochondrion for fission. Subsequently, ubiquitin, PTENinduced kinase (PINK1) and E3 ubiquitin-protein ligase (Parkin) proteins are recruited to the damaged mitochondrion, removed by mitochondrial fission and interact with phagophore, consequently forming an autophagosome. The healthy portion of the mitochondrion undergoes mitochondrial fusion, adding to the existing mitochondrial pool and limiting excessive mitochondrial loss. On the other hand, extensive damage to mitochondria in severe sepsis results in the release of cytochrome c oxidase, and in the formation of an apoptosome when it interacts with apoptotic protease activating factor-1 (Apaf-1) monomers and pro-caspase 9. This leads to downstream activation of caspase 3/7, ultimately resulting in the containment of sepsis-induced damage via apoptosis. Mitochondrial dynamin-like GTPase (OPA-1); dynamin related protein-1 (DRP-1); damage-associated molecular patterns (DAMPs). 
Extensive damage to the mitochondria results in global reduction of mitochondrial permeability, which can lead to accumulation of superoxide eventually, causing the opening of mitochondrial membrane channels. These injuries trigger a series of downstream events, starting with the release of the pro-apoptotic factors Bcl-2-associated X protein BAX and Bcell lymphoma-2 protein. This mediates the release of cytochrome $\mathrm{c}$, which in turn interacts with apoptotic protease activating factor-1 proteins, ultimately forming an apoptosome that triggers a procaspase-9-mediated downstream intrinsic apoptosis cascade [92,93] (Figure 3). This process facilitates the removal of whole mitochondria in severe sepsis and results in a reduction of mitochondrial mass [91], which can further compromise the production of host antioxidants and enhance the production of superoxide (Figure 3). Therefore, ROS-induced damage to the mitochondria in sepsis can result in enhanced ROS production and accumulation, which can contribute to the vicious propagating cycle of oxidative stress, microvascular injury and cellular injury, culminating in AKI. Theoretically then, development of pharmacological therapies aimed towards arresting and/or limiting the production and accumulation of ROS and/or RNS during sepsis should mitigate the propagation of vascular, mitochondrial and cellular injuries, and limit the severity of septic AKI. Below, we discuss pre-clinical and clinical studies that have investigated the use of NAC or vitamin C as a therapeutic strategy to ameliorate oxidative stress induced multi-organ dysfunction in sepsis.

\section{N-Acetylcysteine}

NAC is a powerful synthetic antioxidant that scavenges superoxide, $\mathrm{H}_{2} \mathrm{O}_{2}$ and hydroxyl radicals and replenishes endogenous glutathione levels, thereby enhancing the host's antioxidant defenses [94]. NAC has been shown to suppress the generation of oxygen radicals by human neutrophils and macrophages in vitro [95]; reduce leucocyte-toendothelial cell adhesion and vascular leakage in rodent endotoxemia [96]; and attenuate the activation of nuclear factor kappa-B (NF- $\mathrm{kB}$ ) and interleukin-8 levels in sepsis [97]. Such findings provided the impetus for examining the therapeutic potential of NAC to reverse the deleterious effects of oxidative and nitrosative stress in sepsis.

Multiple experimental studies have investigated NAC either as a prophylactic treatment or as a rescue therapy in early stages of sepsis. In a rodent model of sepsis induced by cecal ligation and puncture (CLP), subcutaneous NAC $(20 \mathrm{mg} / \mathrm{kg})$ treatment initiated $3 \mathrm{~h}$ after CLP reduced systemic inflammation, oxidative stress and mitochondrial dysfunction, leading to a significant improvement in survival (10\% to $40 \%)$ [98]. In rodent endotoxemia, intravenous NAC treatment $(150 \mathrm{mg} / \mathrm{kg}$ bolus $+12.5 \mathrm{mg} / \mathrm{kg} / \mathrm{h})$ initiated $20 \mathrm{~min}$ after administration of lipopolysaccharide reduced serum creatinine and blood urea nitrogen concentrations, an effect associated with reductions in inflammatory cytokines (TNF- $\alpha$ and IL-6) [99]. However, treatments initiated at such early stages of sepsis are arguably of limited relevance to the clinical setting. This is because patients with sepsis are often diagnosed and then receive interventions in the presence of established multi-organ dysfunction, as determined by sequential organ failure assessment (SOFA) scores [100]. In this regard, intravenous treatment with NAC $(150 \mathrm{mg} / \mathrm{kg}$ bolus $+20 \mathrm{mg} / \mathrm{kg} / \mathrm{h})$ in pigs $12 \mathrm{~h}$ after establishment of endotoxemia failed to improve systemic, pulmonary and hepatosplanchnic hemodynamics, or reduce a biomarker of oxidative stress (8-isoprostane), despite elevated glutathione concentrations [101].

Clinical studies that have utilized NAC as an adjunct treatment for sepsis have largely led to disappointing outcomes, particularly when NAC was administered to patients with severe sepsis for longer durations. In most clinical studies, the dose of NAC used in sepsis $(150 \mathrm{mg} / \mathrm{kg})$ was based on the regimen in patients treated for acetaminophen poisoning [102]. In patients with sepsis, intravenous NAC administered over a relatively short period $(150 \mathrm{mg} / \mathrm{kg}$ bolus $+12.5 \mathrm{mg} / \mathrm{kg} / \mathrm{h}$ for $90 \mathrm{~min}$ ) significantly increased cardiac index (5.7 (treatment) vs. 5.0 (usual care) $\mathrm{L} / \mathrm{min} / \mathrm{m}^{2}, p<0.05$ ) and absolute liver blood flow index (3.3 (treatment) vs. 2.7 (usual care) L/min $/ \mathrm{m}^{2}, p=0.01$ ). However, NAC administered over a longer period $(50 \mathrm{mg} / \mathrm{kg}$ over $4 \mathrm{~h}$ followed by $100 \mathrm{mg} / \mathrm{kg} / 24 \mathrm{~h}$ for 
$44 \mathrm{~h}$ ) worsened organ failure (mean SOFA scores at $48 \mathrm{~h}: 7.7 \pm 3.8$ (treatment) vs. $5.1 \pm 2.1$ (usual care), $p<0.05$ ) and did not improve microalbuminuria/creatinine ratio in patients with sepsis [103]. Concerningly, administration of NAC in patients diagnosed with septic shock for durations exceeding $24 \mathrm{~h}$ caused cardiac depression, characterized by reduced cardiac output and exacerbation of hypotension [104]. Similarly, greater requirements for inotropic support were demonstrated in critically ill patients treated with NAC $(150 \mathrm{mg} / \mathrm{kg}$ bolus $+12 \mathrm{mg} / \mathrm{kg} / \mathrm{h}$ ) for durations longer than $24 \mathrm{~h}$ compared with usual care [105]. The highest known dose of NAC administered to patients with sepsis ( 3 g every $6 \mathrm{~h}$ for 3 days) did not significantly improve patient mortality, but had deleterious effects, including increasing the risk of inflammation in association with worsened AKI [106]. However, there is currently a paucity of pharmacokinetic and pharmacodynamic data regarding NAC in sepsis; and the optimal timing and dosages of NAC with respect to onset, disease progression and severity of sepsis remain unknown. Therefore, further clinical and experimental studies are required before the potential for beneficial effects of NAC in sepsis can be completely discounted.

\section{Vitamin C}

Vitamin $C$ is an essential circulating antioxidant which directly scavenges ROS and RNS [107] and replenishes endogenous glutathione concentrations, thereby regenerating the host's antioxidant defenses [108]. Similarly to NAC, vitamin C also causes antiinflammatory actions by inhibiting the activity of NF- $\mathrm{kB}$ and the production of proinflammatory mediators [109]. However, unlike NAC, vitamin C has pleiotropic properties that may be of further benefit to sepsis. Vitamin $C$ is an immune-stimulant which enhances the activity of macrophages [110] and may have the ability to directly inhibit bacterial replication [111]. In cultured human endothelial cells, vitamin C dose-dependently inhibited the TNF- $\alpha$-induced expression of intracellular adhesion molecule- 1 , so it has the potential to reduce microvascular leucocyte plugging and microcirculatory dysfunction [112]. Vitamin $\mathrm{C}$ can also reverse $\mathrm{BH} 4$ oxidation and elevate $\mathrm{BH} 4$-dependent synthesis of nitric oxide from eNOS [113] and/or enhance eNOS bioavailability via a rapid phosphorylation of eNOS-Ser1177 [114], which are effects not observed with antioxidants such as NAC [115]. Vitamin $C$ is also an important cofactor for the synthesis of endogenous vasoconstrictors such as noradrenaline and vasopressin [116], which may further aid in the circulatory management of patients with sepsis who often become unresponsive to vasopressor therapy. Critically-ill patients have abnormally low plasma ascorbate levels [117-119], which is compounded by the inability of humans to naturally synthesis vitamin C, providing another reason for the administration of vitamin $C$ during sepsis [120]. Since enteral uptake is insufficient to normalize plasma ascorbate levels due to saturable intestinal sodium-dependent vitamin C transporters (SVCTs), intravenous treatments are required [121].

Experimental studies have provided compelling evidence for the potential benefits of intravenous vitamin $C$ in sepsis. In murine sepsis induced by CLP, pre-treatment with sodium ascorbate $(200 \mathrm{mg} / \mathrm{kg})$ prevented vascular leakage by inhibiting induction of iNOS, superoxide production and peroxynitrite formation in skeletal muscle tissue [122]. In the same study, sodium ascorbate reduced CLP-induced superoxide generation by preventing NADPH oxidase activation and uncoupling of eNOS [122]. In mice with fecal-induced peritonitis (FIP), ascorbate treatment at $6 \mathrm{~h}$ post-FIP reversed platelet adhesion, improved muscle capillary blood distribution and increased survival, but these beneficial effects were not observed in eNOS knockout mice $[123,124]$. Pre-treatment with sodium ascorbate $(76-200 \mathrm{mg} / \mathrm{kg}$ ) has been demonstrated to attenuate the reduced pressor responsiveness to vasopressors, including noradrenaline and angiotensin II, observed in CLP mice via inhibition of iNOS activity $[125,126]$. Such experimental observations have provided the scientific rationale for clinical trials examining the putative benefits of intravenous vitamin $C$ in human sepsis.

Despite the proposed benefits of vitamin C identified in animal models of early sepsis, its efficacy in human sepsis remains controversial. Two small, single-center randomized 
clinical trials (RCT; $n=24 \& n=28$ ) showed that intravenous administration of ascorbic acid, at doses ranging from 50 to $200 \mathrm{mg} / \mathrm{kg} /$ day, reduced inflammatory biomarkers and SOFA score [127] and improved vasopressor sensitivity $(25 \mathrm{mg} / \mathrm{kg}$ every $6 \mathrm{~h}$ for 3 days) [128]. Another single-center, retrospective before-and-after study $(n=47)$ using a combination therapy of ascorbic acid ( $1.5 \mathrm{~g} ; 4$ times/day) with hydrocortisone and thiamine, identified significant reductions in hospital mortality ( $8.5 \%$ vs. $40.4 \%, p<0.001)$, duration of vasopressor use $(18.3 \pm 9.8 \mathrm{~h}$ vs. $54.9 \pm 28.4 \mathrm{~h}, p<0.001)$ and the requirement for RRT ( $10 \%$ vs. $37 \%, p<0.05)$ at $72 \mathrm{~h}$ after the intervention [129]. However, subsequent multi-center RCTs, VITAMINS [130], ACTS [131] and ATESS [132], that trialed ascorbic acid at $6 \mathrm{~g} /$ day with thiamine with and without corticosteroid for up to 10 days, failed to detect differences in mortality or requirement for RRT in patients with sepsis. The CITRUS-ALI trial which utilized $\sim 16 \mathrm{~g} /$ day of intravenous ascorbic acid for 4 days in patients with sepsis, also did not detect improved mean modified SOFA scores, although a reduction in 28-day mortality from $46 \%$ to $30 \%$ was observed [133]. Sepsis is characterized by a profound systemic inflammatory state, which has been showed to downregulate cellular SVCTs $[134,135]$. Accordingly, higher doses than already trialed in clinical sepsis may be required to circumvent the decrease in SVCTs and drive vitamin C into cells to confer its intracellular benefits.

Since very high doses of vitamin $C$ have been demonstrated to be safe in patients with burns or cancer [136], the pre-clinical safety and efficacy of a mega-dose of sodium ascorbate (150 g for a $40 \mathrm{~kg}$ sheep) was recently investigated in an ovine model of sepsis with established AKI [137]. After $24 \mathrm{~h}$ of established sepsis, mega-dose sodium ascorbate treatment effectively reversed renal medullary ischemia and hypoxia in septic sheep, which was accompanied by a complete reversal of AKI, as detected by profound increases in urine flow and creatinine clearance and normalization of plasma creatinine concentration [137]. Sodium ascorbate also significantly reduced the requirements for noradrenaline needed to restore target blood pressure, reduced arterial blood lactate levels and improved lung function in septic sheep [137]. In addition, a critically ill septic patient with COVID-19 induced hypotension and AKI was treated with intravenous sodium ascorbate (60 g), as compassionate use. As in septic sheep, sodium ascorbate reduced plasma creatinine (118 to $84 \mu \mathrm{mol} / \mathrm{L})$ and increased urine flow $(10$ to $400 \mathrm{~mL} / \mathrm{h}$ ), and mean arterial pressure was restored despite a complete withdrawal of noradrenaline, at least over the $7 \mathrm{~h}$ intervention period [137]. Collectively, these pre-clinical and clinical studies suggest that the optimal dosage, timing and duration of vitamin $C$ therapy are likely to be critical factors that determine its therapeutic efficacy in sepsis, but these factors currently need detailed investigation [120]. Hence, two pilot placebo controlled RCTs are currently underway examining the effects of intravenous mega-dose sodium ascorbate treatment (sodium ascorbate, $60 \mathrm{~g}$ and $120 \mathrm{~g}$ ) on renal outcomes and vasopressor requirements in patients with sepsis (ACTRN12620000651987p; NCT04796636).

\section{Conclusions}

There is evidence that early in sepsis, microcirculatory dysfunction, secondary to inflammation and oxidative stress, results in localized tissue hypoxia and mitochondrial dysfunction, thereby initiating a perpetuating cycle of cellular injury and progressive AKI. Studies of experimental sepsis indicate that the anti-inflammatory and antioxidant actions of NAC and vitamin C confer multi-organ protection, especially when administered either prophylactically or during the early stages of sepsis. However, these putative benefits of NAC and vitamin C seen in animal studies have not always translated to heterogenous populations of patients with sepsis with established multi-organ dysfunction, when administered at various time-points of disease severity over prolonged durations of treatment. Accordingly, preclinical studies in clinically relevant models of sepsis are required to increase our understanding of the mechanisms of action of antioxidants in sepsis and to establish optimal doses given at clinically appropriate time-points of sepsis. Such studies are essential to providing a justified scientific rationale for the design of large, 
double-blinded, placebo controlled, multi-center RCTs, which are essential to identifying the specific characteristics of patients with septic AKI who would most likely benefit from NAC and vitamin C, with respect to their dosages, timing and durations of treatment.

Author Contributions: Conceptualization, Y.R.L. writing-reviewing and editing, C.P.C.O., A.T.-M., A.H.B., R.G.E., C.N.M. and Y.R.L.; figures, C.P.C.O. All authors have read and agreed to the published version of the manuscript.

Funding: The studies referred to from the C.N.M. and Y.R.L. laboratories have been funded by the National Health and Medical Research Council of Australia grants (NHMRC, 454615, 1009280, $1050672,1122455,1188514)$. Y.R.L. was supported by a Future Leader Postdoctoral Fellowship by the National Heart Foundation of Australia (NHF, 101853).

Institutional Review Board Statement: Not applicable.

Informed Consent Statement: Not applicable.

Data Availability Statement: The data presented in this review from YRL and CNM laboratories are available on request from the corresponding author.

Conflicts of Interest: Y.R.L. and C.N.M. have a provisional patent on vitamin C use in sepsis (2020901120).

\section{References}

1. Bagshaw, S.M.; George, C.; Dinu, I.; Bellomo, R. A multi-centre evaluation of the RIFLE criteria for early acute kidney injury in critically ill patients. Nephrol. Dial. Transplant. 2007, 23, 1203-1210. [CrossRef] [PubMed]

2. Bellomo, R.; Kellum, J.A.; Ronco, C.; Wald, R.; Martensson, J.; Maiden, M.; Bagshaw, S.M.; Glassford, N.J.; Lankadeva, Y.R.; Vaara, S.T.; et al. Acute kidney injury in sepsis. Intensive Care Med. 2017, 43, 816-828. [CrossRef] [PubMed]

3. Odutayo, A.; Wong, C.X.; Farkouh, M.; Altman, D.G.; Hopewell, S.; Emdin, C.A.; Hunn, B.H. AKI and long-rerm risk for cardiovascular events and mortality. J. Am. Soc. Nephrol. 2017, 28, 377-387. [CrossRef]

4. Rhodes, A.; Evans, L.E.; Alhazzani, W.; Levy, M.M.; Antonelli, M.; Ferrer, R.; Kumar, A.; Sevransky, J.E.; Sprung, C.L.; Nunnally, M.E.; et al. Surviving sepsis campaign: International guidelines for management of sepsis and septic shock. Intensive Care Med. 2017, 43, 304-377. [CrossRef]

5. Schrier, R.W.; Wang, W. Acute Renal Failure and Sepsis. N. Engl. J. Med. 2004, 351, 159-169. [CrossRef]

6. Takasu, O.; Gaut, J.P.; Watanabe, E.; To, K.; Fagley, R.E.; Sato, B.; Jarman, S.; Efimov, I.R.; Janks, D.L.; Srivastava, A.; et al. Mechanisms of cardiac and renal dysfunction in patients dying of sepsis. Am. J. Respir. Crit. Care Med. 2013, 187, $509-517$. [CrossRef] [PubMed]

7. Lerolle, N.; Nochy, D.; Guérot, E.; Bruneval, P.; Fagon, J.-Y.; Diehl, J.-L.; Hill, G. Histopathology of septic shock induced acute kidney injury: Apoptosis and leukocytic infiltration. Intensive Care Med. 2009, 36, 471-478. [CrossRef]

8. Corrêa, T.D.; Jeger, V.; Pereira, A.J.; Takala, J.; Djafarzadeh, S.; Jakob, S.M. Angiotensin II in septic shock: Effects on tissue perfusion, organ function, and mitochondrial respiration in a porcine model of fecal peritonitis. Crit. Care Med. 2014, 42, e550-e559. [CrossRef] [PubMed]

9. Maiden, M.J.; Otto, S.; Brealey, J.K.; Finnis, M.E.; Chapman, M.J.; Kuchel, T.R.; Nash, C.H.; Edwards, J.; Bellomo, R. Structure and Function of the Kidney in Septic Shock. A Prospective Controlled Experimental Study. Am. J. Respir. Crit. Care Med. 2016, 194, 692-700. [CrossRef]

10. Di Giantomasso, D.; May, C.N.; Bellomo, R. Vital Organ Blood Flow During Hyperdynamic Sepsis. Chest 2003, 124, 1053-1059. [CrossRef]

11. Langenberg, C.; Gobe, G.; Hood, S.; May, C.N.; Bellomo, R. Renal Histopathology During Experimental Septic Acute Kidney Injury and Recovery. Crit. Care Med. 2014, 42, e58-e67. [CrossRef]

12. Ma, S.; Evans, R.; Iguchi, N.; Tare, M.; Parkington, H.C.; Bellomo, R.; May, C.N.; Lankadeva, Y.R. Sepsis-induced acute kidney injury: A disease of the microcirculation. Microcirculation 2018, 26, e12483. [CrossRef] [PubMed]

13. Calzavacca, P.; Evans, R.G.; Bailey, M.; Bellomo, R.; May, C.N. Cortical and Medullary Tissue Perfusion and Oxygenation in Experimental Septic Acute Kidney Injury. Crit. Care Med. 2015, 43, e431-e439. [CrossRef]

14. Lankadeva, Y.R.; Kosaka, J.; Evans, R.G.; Bellomo, R.; May, C.N. Urinary oxygenation as a surrogate marker of medullary oxy-genation during angiotensin II therapy in septic acute kidney injury. Crit. Care Med. 2018, 46, e41-e48. [CrossRef]

15. Lankadeva, Y.R.; Kosaka, J.; Evans, R.G.; Bailey, M.; Bellomo, R.; May, C.N. Intra-renal and urinary oxygenation during norepinephrine resuscitation in ovine septic acute kidney injury. Kidney Int. 2016, 90, 100-108. [CrossRef] [PubMed]

16. Dröge, W. Free Radicals in the Physiological Control of Cell Function. Physiol. Rev. 2002, 82, 47-95. [CrossRef]

17. Kellum, J.A.; Prowle, J. Paradigms of acute kidney injury in the intensive care setting. Nat. Rev. Nephrol. 2018, 14, 217-230. [CrossRef] [PubMed] 
18. Gomez, H.; Ince, C.; De Backer, D.; Pickkers, P.; Payen, D.; Hotchkiss, J.; Kellum, J.A. A unified theory of sepsis-induced acute kidney injury: Inflammation, microcirculatory dysfunction, bioenergetics and the tubular cell adaptation to injury. Shock 2014, 41, 3-11. [CrossRef]

19. Mittal, M.; Siddiqui, M.R.; Tran, K.; Reddy, S.P.; Malik, A.B. Reactive Oxygen Species in Inflammation and Tissue Injury. Antioxid. Redox Signal. 2014, 20, 1126-1167. [CrossRef]

20. Graham, D.B.; Robertson, C.M.; Bautista, J.; Mascarenhas, F.; Diacovo, M.J.; Montgrain, V.; Lam, S.K.; Cremasco, V.; Dunne, W.M.; Faccio, R.; et al. Neutrophil-mediated oxidative burst and host defense are controlled by a Vav-PLCgamma2 signaling axis in mice. J. Clin. Investig. 2007, 117, 3445-3452. [CrossRef] [PubMed]

21. Nguyen, G.T.; Green, E.R.; Mecsas, J. Neutrophils to the ROScue: Mechanisms of NADPH Oxidase Activation and Bacterial Resistance. Front. Cell. Infect. Microbiol. 2017, 7, 373. [CrossRef]

22. Herter, J.M.; Rossaint, J.; Spieker, T.; Zarbock, A. Adhesion Molecules Involved in Neutrophil Recruitment during Sepsis-Induced Acute Kidney Injury. J. Innate Immun. 2014, 6, 597-606. [CrossRef]

23. Fujimi, S.; Ogura, H.; Tanaka, H.; Koh, T.; Hosotsubo, H.; Nakamori, Y.; Kuwagata, Y.; Shimazu, T.; Sugimoto, H. Activated Polymorphonuclear Leukocytes Enhance Production of Leukocyte Microparticles with Increased Adhesion Molecules in Patients with Sepsis. J. Trauma Acute Care Surg. 2002, 52, 443-448. [CrossRef]

24. Ware, L.B.; Fessel, J.P.; May, A.K.; Roberts, L.J. Plasma Biomarkers of Oxidant Stress and Development of Organ Failure in Severe Sepsis. Shock 2011, 36, 12-17. [CrossRef]

25. Satriano, J.A.; Banas, B.; Luckow, B.; Nelson, P.; Schlondorff, D.O. Regulation of RANTES and ICAM-1 expression in murine mesangial cells. J. Am. Soc. Nephrol. 1997, 8, 596-603. [CrossRef]

26. Ley, K.; Laudanna, C.; Cybulsky, M.; Nourshargh, S. Getting to the site of inflammation: The leukocyte adhesion cascade updated. Nat. Rev. Immunol. 2007, 7, 678-689. [CrossRef]

27. Michie, H.R.; Manogue, K.R.; Spriggs, D.R.; Revhaug, A.; O’Dwyer, S.; Dinarello, C.A.; Cerami, A.; Wolff, S.M.; Wilmore, D.W. Detection of Circulating Tumor Necrosis Factor after Endotoxin Administration. N. Engl. J. Med. 1988, 318, 1481-1486. [CrossRef] [PubMed]

28. Cannon, J.G.; Tompkins, R.G.; Gelfand, J.A.; Michie, H.R.; Stanford, G.G.; van der Meer, J.W.; Endres, S.; Lonnemann, G.; Corsetti, J.; Chernow, B.; et al. Circulating interleukin-1 and tumor necrosis factor in septic shock and experimental endotoxin fever. J. Infect. Dis. 1990, 161, 79-84. [CrossRef] [PubMed]

29. Chen, Y.; Jin, S.; Teng, X.; Hu, Z.; Zhang, Z.; Qiu, X.; Tian, D.; Wu, Y. Hydrogen Sulfide Attenuates LPS-Induced Acute Kidney Injury by Inhibiting Inflammation and Oxidative Stress. Oxidative Med. Cell. Longev. 2018, 2018, 6717212. [CrossRef]

30. Ehling, J.L.A.; Babickova, J.; Gremse, F.; Klinkhammer, B.M.; Baetke, S.C.; Knuechel, R.; Kiessling, F.; Floege, J.; Lammers, T.; Boor, P. Quantitative Micro-Computed Tomography Imaging of Vascular Dysfunction in Progressive Kidney Diseases. J. Am. Soc. Nephrol. 2016, 27, 520-532. [CrossRef]

31. Bábíčková, J.; Klinkhammer, B.M.; Buhl, E.M.; Djudjaj, S.; Hoss, M.; Heymann, F.; Tacke, F.; Floege, J.; Becker, J.U.; Boor, P. Regardless of etiology, progressive renal disease causes ultrastructural and functional alterations of peritubular capillaries. Kidney Int. 2017, 91, 70-85. [CrossRef] [PubMed]

32. Trzeciak, S.; Dellinger, R.P.; Parrillo, J.E.; Guglielmi, M.; Bajaj, J.; Abate, N.L.; Arnold, R.C.; Colilla, S.; Zanotti, S.; Hollenberg, S.M. Early microcirculatory perfusion derangements in patients with severe sepsis and septic shock: Relationship to hemody-namics, oxygen transport, and survival. Ann. Emerg. Med. 2007, 49, 88-98. [CrossRef]

33. McNeill, E.; Channon, K.M. The role of tetrahydrobiopterin in inflammation and cardiovascular disease. Thromb. Haemost. 2012, 108, 832-839. [CrossRef] [PubMed]

34. Bendall, J.K.; Alp, N.J.; Warrick, N.; Cai, S.; Adlam, D.; Rockett, K.; Yokoyama, M.; Kawashima, S.; Channon, K.M. Stoichi-ometric relationships between endothelial tetrahydrobiopterin, endothelial NO synthase (eNOS) activity, and eNOS coupling In Vivo: Insights from transgenic mice with endothelial-targeted GTP cyclohydrolase 1 and eNOS overexpression. Circ. Res. 2005, 97, 864-871. [CrossRef]

35. Kuzkaya, N.; Weissmann, N.; Harrison, D.G.; Dikalov, S. Interactions of peroxynitrite, tetrahydrobiopterin, ascorbic acid, and thiols: Implications for uncoupling endothelial nitric-oxide synthase. J. Biol. Chem. 2003, 278, 22546-22554. [CrossRef] [PubMed]

36. Alkaitis, M.S.; Crabtree, M.J. Recoupling the Cardiac Nitric Oxide Synthases: Tetrahydrobiopterin Synthesis and Recycling. Curr. Heart Fail. Rep. 2012, 9, 200-210. [CrossRef]

37. Kietadisorn, R.; Juni, R.P.; Moens, A.L. Tackling endothelial dysfunction by modulating NOS uncoupling: New insights into its pathogenesis and therapeutic possibilities. Am. J. Physiol. Metab. 2012, 302, E481-E495. [CrossRef]

38. Lankadeva, Y.R.; Singh, R.R.; Moritz, K.M.; Parkington, H.C.; Denton, K.M.; Tare, M. Renal Dysfunction Is Associated with a Reduced Contribution of Nitric Oxide and Enhanced Vasoconstriction After a Congenital Renal Mass Reduction in Sheep. Circulation 2015, 131, 280-288. [CrossRef]

39. He, X.; Su, F.; Velissaris, D.; Salgado, D.R.; de Souza Barros, D.; Lorent, S.; Taccone, F.S.; Vincent, J.L.; De Backer, D. Admin-istration of tetrahydrobiopterin improves the microcirculation and outcome in an ovine model of septic shock. Crit. Care Med. 2012, 40, 2833-2840. [CrossRef]

40. Chelazzi, C.; Villa, G.; Mancinelli, P.; De Gaudio, A.R.; Adembri, C. Glycocalyx and sepsis-induced alterations in vascular permeability. Crit. Care 2015, 19, 1-7. [CrossRef] 
41. Butler, M.J.; Down, C.J.; Foster, R.; Satchell, S.C. The Pathological Relevance of Increased Endothelial Glycocalyx Permeability. Am. J. Pathol. 2020, 190, 742-751. [CrossRef]

42. Dane, M.J.C.; Berg, B.M.V.D.; Lee, D.H.; Boels, M.G.S.; Tiemeier, G.L.; Avramut, M.C.; van Zonneveld, A.J.; Van der Vlag, J.; Vink, H.; Rabelink, T.J. A microscopic view on the renal endothelial glycocalyx. Am. J. Physiol. Physiol. 2015, 308, F956-F966. [CrossRef]

43. Wiesinger, A.; Peters, W.; Chappell, D.; Kentrup, D.; Reuter, S.; Pavenstädt, H.; Oberleithner, H.; Kümpers, P. Nanomechanics of the endothelial glycocalyx in experimental sepsis. PLoS ONE 2013, 8, e80905.

44. Marechal, X.; Favory, R.; Joulin, O.; Montaigne, D.; Hassoun, S.; Decoster, B.; Zerimech, F.; Neviere, R. Endothelial Glycocalyx Damage During Endotoxemia Coincides with Microcirculatory Dysfunction and Vascular Oxidative Stress. Shock 2008, 29, 572-576. [CrossRef]

45. Ince, C.; Mayeux, P.R.; Nguyen, T.; Gomez, H.; Kellum, J.A.; Ospina-Tascón, G.A.; Hernandez, G.; Murray, P.; De Backer, D. The Endothelium in Sepsis. Shock 2016, 45, 259-270. [CrossRef]

46. Nelson, A.; Berkestedt, I.; Schmidtchen, A.; Ljunggren, L.; Bodelsson, M. Increased levels of glycosaminoglycans during septic shock: Relation to mortality and the antibacterial actions of plasma. Shock 2008, 30, 623-627. [CrossRef]

47. Yu, W.-K.; McNeil, J.B.; Wickersham, N.E.; Shaver, C.M.; Bastarache, J.A.; Ware, L.B. Vascular endothelial cadherin shedding is more severe in sepsis patients with severe acute kidney injury. Crit. Care 2019, 23, 18. [CrossRef] [PubMed]

48. Clapp, B.R.; Hingorani, A.D.; Kharbanda, R.K.; Mohamed-Ali, V.; Stephens, J.W.; Vallance, P.; MacAllister, R.J. Inflamma-tioninduced endothelial dysfunction involves reduced nitric oxide bioavailability and increased oxidant stress. Cardiovasc. Res. 2004, 64, 172-178. [CrossRef] [PubMed]

49. Souza, A.C.P.; Yuen, P.S.; Star, R.A. Microparticles: Markers and mediators of sepsis-induced microvascular dysfunction, immunosuppression, and AKI. Kidney Int. 2015, 87, 1100-1108. [CrossRef]

50. Lankadeva, Y.R.; Okazaki, N.; Evans, R.G.; Bellomo, R.; May, C.N. Renal Medullary Hypoxia: A New Therapeutic Target for Septic Acute Kidney Injury? Semin. Nephrol. 2019, 39, 543-553. [CrossRef]

51. Evans, R.G.; Lankadeva, Y.R.; Cochrane, A.D.; Marino, B.; Iguchi, N.; Zhu, M.Z.L.; Hood, S.G.; Smith, J.A.; Bellomo, R.; Gardiner, B.S.; et al. Renal haemodynamics and oxygenation during and after cardiac surgery and cardiopulmonary bypass. Acta Physiol. 2018, 222, e12995. [CrossRef]

52. Lankadeva, Y.R.; Cochrane, A.D.; Marino, B.; Iguchi, N.; Hood, S.G.; Bellomo, R.; May, C.N.; Evans, R.G. Strategies that improve renal medullary oxygenation during experimental cardiopulmonary bypass may mitigate postoperative acute kidney injury. Kidney Int. 2019, 95, 1338-1346. [CrossRef]

53. Heyman, S.N.; Reichman, J.; Brezis, M. Pathophysiology of radiocontrast nephropathy: A role for medullary hypoxia. Investig. Radiol. 1999, 34, 685-691. [CrossRef]

54. Tanaka, S.; Tanaka, T.; Nangaku, M. Hypoxia as a key player in the AKI-to-CKD transition. Am. J. Physiol. Physiol. 2014, 307, F1187-F1195. [CrossRef] [PubMed]

55. Ullah, M.; Basile, D.P. Role of Renal Hypoxia in the Progression From Acute Kidney Injury to Chronic Kidney Disease. Semin. Nephrol. 2019, 39, 567-580. [CrossRef]

56. Evans, R.G.; Smith, D.W.; Lee, C.J.; Ngo, J.P.; Gardiner, B.S. What makes the kidney susceptible to hypoxia? Anat. Rec. 2020, 303, 2544-2552. [CrossRef]

57. Evans, R.G.; Ince, C.; Joles, J.A.; Smith, D.W.; May, C.N.; O'Connor, P.M.; Gardiner, B. Haemodynamic influences on kidney oxygenation: Clinical implications of integrative physiology. Clin. Exp. Pharmacol. Physiol. 2013, 40, 106-122. [CrossRef]

58. Calzavacca, P.; Evans, R.; Bailey, M.; Lankadeva, Y.R.; Bellomo, R.; May, C.N. Long-term measurement of renal cortical and medullary tissue oxygenation and perfusion in unanesthetized sheep. Am. J. Physiol. Integr. Comp. Physiol. 2015, 308, R832-R839. [CrossRef]

59. Bonventre, J.V.; Weinberg, J.M. Recent Advances in the Pathophysiology of Ischemic Acute Renal Failure. J. Am. Soc. Nephrol. 2003, 14, 2199-2210. [CrossRef]

60. Evans, R.G.; Gardiner, B.S.; Smith, D.W.; O'Connor, P.M. Intrarenal oxygenation: Unique challenges and the biophysical basis of homeostasis. Am. J. Physiol. Physiol. 2008, 295, F1259-F1270. [CrossRef]

61. Evans, R.G.; Fitzgerald, S. Nitric oxide and superoxide in the renal medulla: A delicate balancing act. Curr. Opin. Nephrol. Hypertens. 2005, 14, 9-15. [CrossRef] [PubMed]

62. Lankadeva, Y.R.; Kosaka, J.; Iguchi, N.; Evans, R.; Booth, L.C.; Bellomo, R.; May, C.N. Effects of Fluid Bolus Therapy on Renal Perfusion, Oxygenation, and Function in Early Experimental Septic Kidney Injury. Crit. Care Med. 2019, 47, e36-e43. [CrossRef]

63. Iguchi, N.; Lankadeva, Y.R.; Mori, T.A.; Osawa, E.A.; Cutuli, S.L.; Evans, R.G.; Bellomo, R.; May, C.N. Furosemide reverses medullary tissue hypoxia in ovine septic acute kidney injury. Am. J. Physiol. Integr. Comp. Physiol. 2019, 317, R232-R239. [CrossRef]

64. Osawa, E.A.; Cutuli, S.L.; Bitker, L.; Canet, E.; Cioccari, L.; Iguchi, N.; Lankadeva, Y.R.; Eastwood, G.M.; Evans, R.G.; May, C.N.; et al. Effect of furosemide on urinary oxygenation in patients with septic shock. Blood Purif. 2019, 23, 1-10. [CrossRef]

65. O'Connor, P.M.; Kett, M.M.; Anderson, W.P.; Evans, R. Renal medullary tissue oxygenation is dependent on both cortical and medullary blood flow. Am. J. Physiol. Physiol. 2006, 290, F688-F694. [CrossRef]

66. Haase, V.H. Hypoxia-inducible factors in the kidney. Am. J. Physiol. Physiol. 2006, 291, F271-F281. [CrossRef]

67. Ke, Q.; Costa, M. Hypoxia-Inducible Factor-1 (HIF-1). Mol. Pharmacol. 2006, 70, 1469-1480. [CrossRef] 
68. Beck, I.; Weinmann, R.; Caro, J. Characterization of hypoxia-responsive enhancer in the human erythropoietin gene shows presence of hypoxia-inducible 120-Kd nuclear DNA-binding protein in erythropoietin-producing and nonproducing cells. Blood 1993, 82, 704-711. [CrossRef]

69. Lee, F.S.; Percy, M.J. The HIF Pathway and Erythrocytosis. Annu. Rev. Pathol. Mech. Dis. 2011, 6, 165-192. [CrossRef]

70. Melillo, G.; Musso, T.; Sica, A.; Taylor, L.S.; Cox, G.W.; Varesio, L. A hypoxia-responsive element mediates a novel pathway of activation of the inducible nitric oxide synthase promoter. J. Exp. Med. 1995, 182, 1683-1693. [CrossRef]

71. Higgins, D.F.; Kimura, K.; Bernhardt, W.M.; Shrimanker, N.; Akai, Y.; Hohenstein, B.; Saito, Y.; Johnson, R.S.; Kretzler, M.; Cohen, C.D.; et al. Hypoxia promotes fibrogenesis In Vivo via HIF-1 stimulation of epithelial-to-mesenchymal transition. J. Clin. Investig. 2007, 117, 3810-3820. [CrossRef]

72. Parikh, S.M.; Yang, Y.; He, L.; Tang, C.; Zhan, M.; Dong, Z. Mitochondrial Function and Disturbances in the Septic Kidney. Semin. Nephrol. 2015, 35, 108-119. [CrossRef]

73. Ince, C.; Mik, E.G. Microcirculatory and mitochondrial hypoxia in sepsis, shock, and resuscitation. J. Appl. Physiol. 2016, 120, 226-235. [CrossRef] [PubMed]

74. Chandel, N.S.; Maltepe, E.; Goldwasser, E.; Mathieu, C.E.; Simon, M.C.; Schumacker, P.T. Mitochondrial reactive oxygen species trigger hypoxia-induced transcription. Proc. Natl. Acad. Sci. USA 1998, 95, 11715-11720. [CrossRef] [PubMed]

75. Scherz-Shouval, R.; Shvets, E.; Fass, E.; Shorer, H.; Gil, L.; Elazar, Z. Reactive oxygen species are essential for autophagy and specifically regulate the activity of Atg4. EMBO J. 2007, 26, 1749-1760. [CrossRef]

76. Cruz, C.M.; Rinna, A.; Forman, H.J.; Ventura, A.L.; Persechini, P.M.; Ojcius, D.M. ATP activates a reactive oxygen spe-ciesdependent oxidative stress response and secretion of proinflammatory cytokines in macrophages. J. Biol. Chem. 2007, 282, 2871-2879. [CrossRef] [PubMed]

77. Bar-Or, D.; Carrick, M.M.; Mains, C.W.; Rael, L.T.; Slone, D.; Brody, E.N. Sepsis, oxidative stress, and hypoxia: Are there clues to better treatment? Redox Rep. 2015, 20, 193-197. [CrossRef] [PubMed]

78. Nagar, H.; Piao, S.; Kim, C.-S. Role of Mitochondrial Oxidative Stress in Sepsis. Acute Crit. Care 2018, 33, 65-72. [CrossRef] [PubMed]

79. Guzy, R.D.; Schumacker, P.T. Oxygen sensing by mitochondria at complex III: The paradox of increased reactive oxygen species during hypoxia. Exp. Physiol. 2006, 91, 807-819. [CrossRef]

80. Chandel, N.S.; McClintock, D.S.; Feliciano, C.E.; Wood, T.M.; Melendez, J.A.; Rodriguez, A.M.; Schumacker, P.T. Reactive oxygen species generated at mitochondrial complex III stabilize hypoxia-inducible factor-1alpha during hypoxia: $\mathrm{A}$ mechanism of $\mathrm{O}_{2}$ sensing. J. Biol. Chem. 2000, 275, 25130-25138. [CrossRef]

81. Hernansanz-Agustín, P.; Ramos, E.; Navarro, E.; Parada, E.; Sánchez-López, N.; Peláez-Aguado, L.; Cabrera-García, J.D.; Tello, D.; Buendia, I.; Marina, A.; et al. Mitochondrial complex I deactivation is related to superoxide production in acute hypoxia. Redox Biol. 2017, 12, 1040-1051. [CrossRef] [PubMed]

82. Sureshbabu, A.; Patino, E.; Ma, K.C.; Laursen, K.; Finkelsztein, E.J.; Akchurin, O.; Muthukumar, T.; Ryter, S.W.; Gudas, L.; Choi, A.M.K.; et al. RIPK3 promotes sepsis-induced acute kidney injury via mitochondrial dysfunction. JCI Insight. 2018, 3, e98411. [CrossRef]

83. Kitur, K.; Wachtel, S.; Brown, A.; Wickersham, M.; Paulino, F.; Peñaloza, H.F.; Soong, G.; Bueno, S.; Parker, D.; Prince, A. Necroptosis Promotes Staphylococcus aureus Clearance by Inhibiting Excessive Inflammatory Signaling. Cell Rep. 2016, 16, 2219-2230. [CrossRef]

84. Duprez, L.; Takahashi, N.; Van Hauwermeiren, F.; Vandendriessche, B.; Goossens, V.; Berghe, T.V.; Declercq, W.; Libert, C.; Cauwels, A.; Vandenabeele, P. RIP Kinase-Dependent Necrosis Drives Lethal Systemic Inflammatory Response Syndrome. Immunity 2011, 35, 908-918. [CrossRef]

85. Brealey, D.; Brand, M.; Hargreaves, I.; Heales, S.; Land, J.; Smolenski, R.; Davies, N.A.; Cooper, C.; Singer, M. Association between mitochondrial dysfunction and severity and outcome of septic shock. Lancet 2002, 360, 219-223. [CrossRef]

86. Plotnikov, E.Y.; Pevzner, I.B.; Zorova, L.D.; Chernikov, V.P.; Prusov, A.N.; Kireev, I.I.; Silachev, D.N.; Skulachev, V.P.; Zorov, D.B. Mitochondrial damage and mitochondria-Targeted antioxidant protection in LPS-induced acute kidney injury. Antioxidants 2019, 8, 176. [CrossRef]

87. Pathak, E.; MacMillan-Crow, L.A.; Mayeux, P.R. Role of Mitochondrial Oxidants in an In Vitro Model of Sepsis-Induced Renal Injury. J. Pharmacol. Exp. Ther. 2012, 340, 192-201. [CrossRef]

88. Ding, Y.; Zheng, Y.; Huang, J.; Peng, W.; Chen, X.; Kang, X.; Zeng, Q. UCP2 ameliorates mitochondrial dysfunction, inflammation, and oxidative stress in lipopolysaccharide-induced acute kidney injury. Int. Immunopharmacol. 2019, 71, 336-349. [CrossRef]

89. Divakaruni, A.S.; Brand, M.D. The Regulation and Physiology of Mitochondrial Proton Leak. Physiology 2011, 26, 192-205. [CrossRef] [PubMed]

90. Liu, J.-X.; Yang, C.; Zhang, W.-H.; Su, H.-Y.; Liu, Z.-J.; Pan, Q.; Liu, H.-F. Disturbance of mitochondrial dynamics and mitophagy in sepsis-induced acute kidney injury. Life Sci. 2019, 235, 116828. [CrossRef] [PubMed]

91. Van der Slikke, E.C.; Star, B.S.; van Meurs, M.; Henning, R.H.; Moser, J.; Bouma, H.R. Sepsis is associated with mitochondrial DNA damage and a reduced mitochondrial mass in the kidney of patients with sepsis-AKI. Crit. Care 2021, 25, 1-13. [CrossRef] [PubMed]

92. Cain, K.; Bratton, S.B.; Cohen, G.M. The Apaf-1 apoptosome: A large caspase-activating complex. Biochimie 2002, 84, 203-214. [CrossRef] 
93. Yuan, S.; Akey, C.W. Apoptosome structure, assembly, and procaspase activation. Structure 2013, 21, 501-515. [CrossRef] [PubMed]

94. Aruoma, O.I.; Halliwell, B.; Hoey, B.M.; Butler, J. The antioxidant action of N-acetylcysteine: Its reaction with hydrogen per-oxide, hydroxyl radical, superoxide, and hypochlorous acid. Free Radic. Biol. Med. 1989, 6, 593-597. [CrossRef]

95. Kharazmi, A.; Nielsen, H.; Schiøtz, P.O. N-acetylcysteine inhibits human neutrophil and monocyte chemotaxis and oxidative metabolism. Int. J. Immunopharmacol. 1988, 10, 39-46. [CrossRef]

96. Schmidt, H.; Schmidt, W.; Muller, T.; Bohrer, H.; Gebhard, M.M.; Martin, E. N-acetylcysteine attenuates endotoxin-induced leukocyte-endothelial cell adhesion and macromolecular leakage In Vivo. Crit. Care Med. 1997, 25, 858-863. [CrossRef]

97. Paterson, R.L.; Galley, H.F.; Webster, N.R. The effect of N-acetylcysteine on nuclear factor-kB activation, interleukin-6, interleukin8, and intercellular adhesion molecule-1 expression in patients with sepsis. Crit. Care Med. 2003, 31, 2574-2578. [CrossRef]

98. Ritter, C.; Andrades, M.E.; Reinke, A.; Menna-Barreto, S.; Moreira, J.C.F.; Dal-Pizzol, F. Treatment with N-acetylcysteine plus deferoxamine protects rats against oxidative stress and improves survival in sepsis. Crit. Care Med. 2004, 32, 342-349. [CrossRef]

99. Hsu, B.-G.; Lee, R.-P.; Yang, F.-L.; Harn, H.-J.; Chen, H.I. Post-treatment with N-acetylcysteine ameliorates endotoxin shockinduced organ damage in conscious rats. Life Sci. 2006, 79, 2010-2016. [CrossRef]

100. Singer, M.; Deutschman, C.S.; Seymour, C.C.; Shankar-Hari, M.; Annane, D.; Bauer, M.; Bellomo, R.; Bernard, G.R.; Chiche, J.-D.; Coopersmith, C.C.; et al. The Third International Consensus Definitions for Sepsis and Septic Shock (Sepsis-3). JAMA 2016, 315, 801-810. [CrossRef]

101. Vassilev, D.; Hauser, B.; Bracht, H.; Iványi, Z.; Schoaff, M.; Asfar, P.; Vogt, J.; Wachter, U.; Schelzig, H.; Georgieff, M.; et al. Systemic, pulmonary, and hepatosplanchnic effects of $\mathrm{N}$-acetylcysteine during long-term porcine endotoxemia. Crit. Care Med. 2004, 32, 525-532. [CrossRef]

102. Szakmany, T.; Hauser, B.; Matejovic, M.; Radermacher, P. N-acetylcysteine for sepsis and systemic inflammatory response in adults. Cochrane Database Syst. Rev. 2007, CD006616. [CrossRef]

103. Spapen, H.D.; Diltoer, M.W.; Nguyen, D.N.; Hendrickx, I.; Huyghens, L.P. Effects of N-acetylcysteine on microalbuminuria and organ failure in acute severe sepsis: Results of a pilot study. Chest 2005, 127, 1413-1419. [CrossRef] [PubMed]

104. Peake, S.L.; Moran, J.L.; Leppard, P.I. N-acetyl-L-cysteine depresses cardiac performance in patients with septic shock. Crit. Care Med. 1996, 24, 1302-1310. [CrossRef] [PubMed]

105. Molnár, Z.; Shearer, E.; Lowe, D. N-Acetylcysteine treatment to prevent the progression of multisystem organ failure: A pro-spective, randomized, placebo-controlled study. Crit. Care Med. 1999, 27, 1100-1104. [CrossRef]

106. Najafi, A.; Mojtahedzadeh, M.; Ahmadi, K.H.; Abdollahi, M.; Mousavi, M.; Chelkeba, L.; Najmeddin, F.; Ahmadi, A. The immunological benefit of higher dose $\mathrm{N}$-acetyl cysteine following mechanical ventilation in critically ill patients. DARU J. Pharm. Sci. 2014, 22, 57. [CrossRef]

107. Padayatty, S.J.; Levine, M. Vitamin C: The known and the unknown and Goldilocks. Oral Dis. 2016, 22, 463-493. [CrossRef]

108. Buettner, G.R.; Jurkiewicz, B.A. Catalytic Metals, Ascorbate and Free Radicals: Combinations to Avoid. Radiat. Res. 1996, $145,532$. [CrossRef]

109. Cárcamo, J.M.; Pedraza, A.; Bórquez-Ojeda, O.; Golde, D.W. Vitamin C suppresses TNF alpha-induced NF kappa B activation by inhibiting I kappa B alpha phosphorylation. Biochemistry 2002, 41, 12995-13002. [CrossRef]

110. Victor, V.V.; Guayerbas, N.; Puerto, M.; Medina, S.; De la Fuente, M. Ascorbic acid modulates In Vitro the function of mac-rophages from mice with endotoxic shock. Immunopharmacology 2000, 46, 89-101. [CrossRef]

111. Armour, J.; Tyml, K.; Lidington, D.; Wilson, J.X. Ascorbate prevents microvascular dysfunction in the skeletal muscle of the septic rat. J. Appl. Physiol. 2001, 90, 795-803. [CrossRef]

112. Mo, S.-J.; Son, E.-W.; Rhee, D.-K.; Pyo, S. Modulation of tnf- $\alpha$-induced icam-1 expression, $\mathrm{NO}$ and $\mathrm{H}_{2} \mathrm{O}_{2}$ production by alginate, allicin and ascorbic acid in human endothelial cells. Arch. Pharmacal Res. 2003, 26, 244-251. [CrossRef] [PubMed]

113. Kim, H.J.; Lee, S.I.; Lee, D.-H.; Smith, D.; Jo, H.; Schellhorn, H.E.; Boo, Y.C. Ascorbic acid synthesis due to 1-gulono-1,4-lactone oxidase expression enhances NO production in endothelial cells. Biochem. Biophys. Res. Commun. 2006, 345, 1657-1662. [CrossRef] [PubMed]

114. Ladurner, A.; Schmitt, C.A.; Schachner, D.; Atanasov, A.; Werner, E.R.; Dirsch, V.M.; Heiss, E.H. Ascorbate stimulates endothelial nitric oxide synthase enzyme activity by rapid modulation of its phosphorylation status. Free Radic. Biol. Med. 2012, 52, $2082-2090$. [CrossRef] [PubMed]

115. Schneider, M.P.; Delles, C.; Schmidt, B.M.; Oehmer, S.; Schwarz, T.K.; Schmieder, R.E.; John, S. Superoxide scavenging effects of $\mathrm{N}$-acetylcysteine and vitamin $\mathrm{C}$ in subjects with essential hypertension. Am. J. Hypertens. 2005, 18, 1111-1117. [CrossRef]

116. Carr, A.C.; Shaw, G.M.; Fowler, A.A.; Natarajan, R. Ascorbate-dependent vasopressor synthesis: A rationale for vitamin C administration in severe sepsis and septic shock? Crit. Care 2015, 19, 418. [CrossRef]

117. Hudson, E.P.; Collie, J.T.; Fujii, T.; Luethi, N.; Udy, A.A.; Doherty, S.; Eastwood, G.; Yanase, F.; Naorungroj, T.; Bitker, L.; et al. Pharmacokinetic data support 6-hourly dosing of intravenous vitamin C to critically ill patients with septic shock. Crit. Care Resusc 2019, 21, 236-242.

118. Schorah, C.J.; Downing, C.; Piripitsi, A.; Gallivan, L.; Al-Hazaa, A.H.; Sanderson, M.J.; Bodenham, A. Total vitamin C, ascorbic acid, and dehydroascorbic acid concentrations in plasma of critically ill patients. Am. J. Clin. Nutr. 1996, 63, 760-765. [CrossRef]

119. Carr, A.C.; Rosengrave, P.C.; Bayer, S.; Chambers, S.; Mehrtens, J.; Shaw, G.M. Hypovitaminosis C and vitamin C deficiency in critically ill patients despite recommended enteral and parenteral intakes. Crit. Care 2017, 21, 1-10. [CrossRef] 
120. May, C.N.; Bellomo, R.; Lankadeva, Y.R. Therapeutic potential of mega-dose vitamin C to reverse organ dysfunction in sepsis and COVID-19. Br. J. Pharmacol. 2021. [CrossRef]

121. Wilson, J.X. Evaluation of Vitamin C for Adjuvant Sepsis Therapy. Antioxid. Redox Signal. 2013, 19, 2129-2140. [CrossRef]

122. Zhou, G.; Kamenos, G.; Pendem, S.; Wilson, J.X.; Wu, F. Ascorbate protects against vascular leakage in cecal ligation and puncture-induced septic peritonitis. Am. J. Physiol. Integr. Comp. Physiol. 2012, 302, R409-R416. [CrossRef]

123. Secor, D.; Li, F.; Ellis, C.; Sharpe, M.D.; Gross, P.L.; Wilson, J.X.; Tyml, K. Impaired microvascular perfusion in sepsis requires activated coagulation and P-selectin-mediated platelet adhesion in capillaries. Intensive Care Med. 2010, 36, 1928-1934. [CrossRef] [PubMed]

124. Tyml, K.; Li, F.; Wilson, J.X. Septic impairment of capillary blood flow requires nicotinamide adenine dinucleotide phosphate oxidase but not nitric oxide synthase and is rapidly reversed by ascorbate through an endothelial nitric oxide syn-thase-dependent mechanism. Crit. Care Med. 2008, 36, 2355-2362. [CrossRef] [PubMed]

125. Wu, F.; Wilson, J.X.; Tyml, K. Ascorbate inhibits iNOS expression and preserves vasoconstrictor responsiveness in skeletal muscle of septic mice. Am. J. Physiol. Integr. Comp. Physiol. 2003, 285, R50-R56. [CrossRef] [PubMed]

126. Wu, F.; Wilson, J.X.; Tyml, K. Ascorbate protects against impaired arteriolar constriction in sepsis by inhibiting inducible nitric oxide synthase expression. Free Radic. Biol. Med. 2004, 37, 1282-1289. [CrossRef]

127. Fowler, A.A., III; Syed, A.A.; Knowlson, S.; Sculthorpe, R.; Farthing, D.; De Wilde, C.; Farthing, C.A.; Larus, T.L.; Martin, E.; Brophy, D.F.; et al. Phase I safety trial of intravenous ascorbic acid in patients with severe sepsis. J. Transl. Med. 2014, 12, 32. [CrossRef]

128. Khalili, H.; Zabet, M.H.; Mohammadi, M.; Ramezani, M. Effect of high-dose Ascorbic acid on vasopressor's requirement in septic shock. J. Res. Pharm. Pract. 2016, 5, 94-100. [CrossRef] [PubMed]

129. Marik, P.E.; Khangoora, V.; Rivera, R.; Hooper, M.H.; Catravas, J. Hydrocortisone, vitamin C, and thiamine for the treatment of severe sepsis and septic shock: A retrospective before-after study. Chest 2017, 151, 1229-1238. [CrossRef]

130. Fujii, T.; Luethi, N.; Young, P.J.; Frei, D.R.; Eastwood, G.M.; French, C.J.; Deane, A.M.; Shehabi, Y.; Hajjar, L.A.; Oliveira, G.; et al. Effect of vitamin $\mathrm{C}$, hydrocortisone, and thiamine vs hydrocortisone alone on time alive and free of vasopressor support among patients with septic shock: The VITAMINS randomized clinical trial. JAMA 2020, 323, 423-431. [CrossRef]

131. Moskowitz, A.; Huang, D.T.; Hou, P.C.; Gong, J.; Doshi, P.B.; Grossestreuer, A.V.; Andersen, L.W.; Ngo, L.; Sherwin, R.L.; Berg, K.M.; et al. Effect of ascorbic acid, corticosteroids, and thiamine on organ injury in septic shock: The ACTS randomized clinical trial. JAMA 2020, 324, 642-650. [CrossRef]

132. Hwang, S.Y.; Ryoo, S.M.; Park, J.E.; Jo, Y.H.; Jang, D.H.; Suh, G.J.; Kim, T.; Kim, Y.J.; Kim, S.; Cho, H.; et al. Combination therapy of vitamin $\mathrm{C}$ and thiamine for septic shock: A multi-centre, double-blinded randomized, controlled study. Intensive Care Med. 2020, 46, 2015-2025. [CrossRef] [PubMed]

133. Fowler, A.A., III; Truwit, J.D.; Hite, R.D.; Morris, P.E.; De Wilde, C.; Priday, A.; Fisher, B.; Thacker, L.R., II; Natarajan, R.; Brophy, D.F.; et al. Effect of vitamin $\mathrm{C}$ infusion on organ failure and biomarkers of inflammation and vascular injury in patients with sepsis and severe acute respiratory failure: The CITRIS-ALI randomized clinical trial. JAMA 2019, 322, 1261-1270. [CrossRef] [PubMed]

134. Subramanian, V.S.; Sabui, S.; Moradi, H.; Marchant, J.S.; Said, H.M. Inhibition of intestinal ascorbic acid uptake by lipopolysaccharide is mediated via transcriptional mechanisms. Biochim. Biophys. Acta Biomembr. 2018, 1860, 556-565. [CrossRef]

135. Subramanian, V.S.; Sabui, S.; Subramenium, G.A.; Marchant, J.S.; Said, H.M. Tumor necrosis factor alpha reduces intestinal vitamin C uptake: A role for NF-kB-mediated signaling. Am. J. Physiol. Gastrointest. Liver Physiol. 2018, 315, G241-G248. [CrossRef] [PubMed]

136. Yanase, F.; Fujii, T.; Naorungroj, T.; Belletti, A.; Luethi, N.; Carr, A.C.; Young, P.J.; Bellomo, R. Harm of IV high-dose vitamin C therapy in adult patients: A scoping review. Crit. Care Med. 2020, 48, e620-e628. [CrossRef]

137. Lankadeva, Y.R.; Peiris, R.M.; Okazaki, N.; Birchall, I.E.; Trask-Marino, A.; Dornom, A.; Vale, T.A.M.; Evans, R.G.; Yanase, F.; Bellomo, R.; et al. Reversal of the pathophysiological responses to gram-negative sepsis by megadose vitamin C. Crit. Care Med. 2021, 49, e179-e190. [CrossRef] 